\title{
Population dynamics of two antilisterial cheese surface consortia revealed by temporal temperature gradient gel electrophoresis
}

\author{
Emmanuelle Roth ${ }^{1,2}$, Susanne Miescher Schwenninger ${ }^{1 *}$, Madlen Hasler ${ }^{1}$, Elisabeth Eugster-Meier ${ }^{2}$,
} Christophe Lacroix ${ }^{1}$

\begin{abstract}
Background: Surface contamination of smear cheese by Listeria spp. is of major concern for the industry. Complex smear ecosystems have been shown to harbor antilisterial potential but the microorganisms and mechanisms involved in the inhibition mostly remain unclear, and are likely related to complex interactions than to production of single antimicrobial compounds. Bacterial biodiversity and population dynamics of complex smear ecosystems exhibiting antilisterial properties in situ were investigated by Temporal temperature gradient gel electrophoresis (TTGE), a culture independent technique, for two microbial consortia isolated from commercial Raclette type cheeses inoculated with defined commercial ripening cultures (F) or produced with an old-young smearing process (M).

Results: TTGE revealed nine bacterial species common to both $F$ and $M$ consortia, but consortium $F$ exhibited a higher diversity than consortium $\mathrm{M}$, with thirteen and ten species, respectively. Population dynamics were studied after application of the consortia on fresh-produced Raclette cheeses. TTGE analyses revealed a similar sequential development of the nine species common to both consortia. Beside common cheese surface bacteria (Staphylococcus equorum, Corynebacterium spp., Brevibacterium linens, Microbacterium gubbeenense, Agrococcus casei), the two consortia contained marine lactic acid bacteria (Alkalibacterium kapii, Marinilactibacillus psychrotolerans) that developed early in ripening (day 14 to 20), shortly after the growth of staphylococci (day 7). A decrease of Listeria

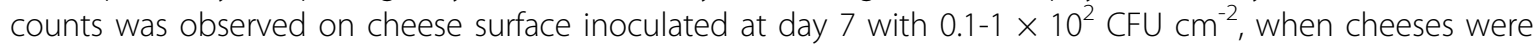
smeared with consortium F or M. Listeria counts went below the detection limit of the method between day 14 and 28 and no subsequent regrowth was detected over 60 to 80 ripening days. In contrast, Listeria grew to high counts $\left(10^{5} \mathrm{CFU} \mathrm{\textrm {cm } ^ { - 2 }}\right)$ on cheeses smeared with a defined surface culture.

Conclusions: This work reports the first population dynamics study of complex smear ecosystems exhibiting in situ antilisterial activity. TTGE revealed the presence of marine lactic acid bacteria that are likely related to the strong Listeria inhibition, as their early development in the smear occurred simultaneously with a decrease in Listeria cell count.
\end{abstract}

\section{Background}

The surface of traditional smear-ripened cheeses is colonized by a complex microbial ecosystem. Its biodiversity has been investigated by identification of cultivable isolates with molecular techniques, such as Pulsed-field gel electrophoresis (PFGE), Repetitive sequence-based PCR

\footnotetext{
* Correspondence: susanne.miescher@ilw.agrl.ethz.ch

'Laboratory of Food Biotechnology, Institute of Food Science and Nutrition,
} ETH-Zurich, 8092 Zurich, Switzerland transform infrared spectroscopy (FTIR) [1-3]. Biodiversity studies using culture independent fingerprinting techniques, such as Temporal temperature gradient gel electrophoresis (TTGE), Denaturing gradient gel electrophoresis (DGGE), Single strand conformation polymorphism (SSCP) and Terminal restriction fragment length polymorphism (T-RFLP), have revealed the presence of additional uncultivable species [4-6]. The development of the smear is a dynamic process driven by 
metabiosis leading to the successive growth of several microbial communities. The first microorganisms to colonize the surface are yeasts. Yeasts' deacidification properties create a favorable environment for the next populations, mainly staphylococci followed by coryneforms. These two shifts in the microbial community structure of the smear have been observed in multiple studies [6-8]. Various marine bacteria have also been detected recently on cheese surface $[5,9,10]$. Population dynamics of complex cheese surface ecosystems at species level have been studied by cultivation methods, but these approaches are necessarily limited by the selectivity of the cultivation media chosen. Alternatively, fingerprinting techniques can be used to generate data on main populations of such ecosystems. These methods are fast and can give a more exhaustive view of the biodiversity in cheese but they are greatly influenced by the quality of DNA extraction protocols and bias may be introduced by the PCR amplification step [11]. The main advantage of TTGE/DGGE over other available fingerprinting techniques is the possibility to identify detected species by sequencing of DNA fragments after excision from the TTGE/DGGE gel [11]. TTGE/DGGE has been applied to study dominant bacteria of dairy products, enabling detection of species accounting for at least 1 to $10 \%$ of the total flora, depending on the amplification efficiency of the PCR step for a given species $[4,12]$.

Surface contamination of smear cheese by Listeria monocytogenes is of concern for the industry since listeriosis breakouts have been associated with consumption of cheese [13]. Improvements in hygienic conditions and application of safety guidelines failed to reduce the contamination frequency to an acceptable level [14]. Growth of Listeria on cheese surface is closely linked to the development of the surface ecosystems and is primarily supported by yeast growth, which leads to deacidification and provides nutrients for bacterial growth. Listeria sp. has been shown to grow easily on smear cheeses when defined ripening cultures containing Debaryomyces hansenii, Geotrichum candidum and Brevibacterium linens were used $[15,16]$. Certain complex consortia naturally developing on smear cheese surface have been shown to inhibit Listeria sp. in situ $[9,15,17]$. In vitro studies of these anti-listerial activities led to the isolation of bacteriocin-producing strains among ripening microorganisms in certain cases $[18,19]$. Application of the bacteriocin producing strain on artificially contaminated cheeses failed however to fully restore the inhibition [15] or disturbed the development of the smear [20]. A better knowledge of microbial biodiversity and in situ population dynamics is crucial to identifying species that may be involved in the inhibition. Saubusse et al. [21] successfully used this approach for detecting antilisterial flora naturally developing in the core of Saint-Nectaire type cheese.

The objective of the present study was therefore to investigate population dynamics of complex cheese surface consortia with respect to their in situ inhibition properties. Two surface consortia were isolated from commercial Raclette type cheeses. TTGE was used for assessing biodiversity of both consortia at species level. An in-house database for species-level identification of the bands appearing in the TTGE fingerprints was developed with cultivable isolates. The two complex consortia or a control flora (defined commercial culture) were then applied on freshly-produced Raclette cheeses that were artificially contaminated with Listeria innocua. Population dynamics and Listeria growth were monitored over 60 to 80 ripening days.

\section{Results}

\section{Bacterial biodiversity of cheese surface consortia by} cultivation - Development of a TTGE profiles database

Consortium $\mathrm{F}$ was serial plated on five selective and non-selective media. A total of 128 cultivable isolates were subjected to TTGE fingerprinting analysis and grouped into 16 TTGE profiles. One representative isolate of each profile was randomly selected and subjected to $16 \mathrm{~S}$ rDNA sequencing. Isolates displaying identical TTGE profiles but isolated from different cultivation media or exhibiting different macroscopic or microscopic morphologies were also subjected to $16 \mathrm{~S}$ rDNA sequencing analyses. The presence of 15 species was detected by cultivation, with 7 dominant species enumerated on TGYA, the medium used for the determination of total cell count (Table 1). The number of bands and the corresponding migration lengths were recorded in a database (Figure 1). A majority of species displayed TTGE profiles with a single band for all isolates. Three species showed strain variations in TTGE profiles, with some strains harboring 1 to 5 supplementary bands (Figure 1). In addition, several species had indistinguishable TTGE profiles. Profile 5 corresponded to both Brachybacterium sp. and Arthrobacter arilaitensis, profile 12 to Staphylococcus equorum, Staphylococcus epidermidis and Facklamia tabacinasalis, and profile 16 to both Lactococcus lactis and Marinilactibacillus psychrotolerans (Figure 1). Low-GC bacteria Lc. lactis and M. psychrotolerans could not be distinguished on low-GC gel whereas high-GC gel revealed specific bands for the two species (bands z and z', respectively, in Figure 2). The database (Figure 1) contained a total of 16 TTGE profiles corresponding to 15 species. It was used as reference for species-level identification in TTGE fingerprints obtained by the culture independent approach. 
Table 1 Bacterial composition of cheese surface consortium $F$ by a culture dependent method $^{1}$

\begin{tabular}{|c|c|c|c|c|c|}
\hline Bacterial species & Accession number ${ }^{2}$ & Similarity (\%) & Isolation media $^{3}$ & Viable count $\left[\mathrm{CFU} \mathrm{\textrm {cm } ^ { - 2 } ]}\right.$ & Percentage on TGYA \\
\hline $\begin{array}{l}\text { Brevibacterium linens } \\
\text { (or Brevibacterium aurantiacum }{ }^{4} \text { ) }\end{array}$ & $\begin{array}{l}\text { GenBank:AJ315491 } \\
\text { (GenBank:X765664) }\end{array}$ & $\begin{array}{l}95.5-98.0 \\
(97.8)\end{array}$ & TGYA & $7.5 .10^{8}$ & $32.5 \%$ \\
\hline Staphylococcus vitulinus & GenBank:NR_024670 & 99.6 & TGYA & $6.0 .10^{8}$ & $26.0 \%$ \\
\hline Brachybacterium tyrofermentans & GenBank:X91657 & 97.9 & TGYA & $4.5 \cdot 10^{8}$ & $19.5 \%$ \\
\hline Corynebacterium casei & GenBank:DQ361013 & 100.0 & TGYA & $1.5 .10^{8}$ & $6.5 \%$ \\
\hline Microbacterium gubbeenense & GenBank:AF263564 & 97.9 & TGYA & $1.5 .10^{8}$ & $6.5 \%$ \\
\hline Marinilactibacillus psychrotolerans & GenBank:AB083413 & 99.8 & TGYA & $1.5 .10^{8}$ & $6.5 \%$ \\
\hline Brachybacterium sp. & GenBank:AF513397 & 99.9 & TGYA & $0.7 .10^{8}$ & $3.0 \%$ \\
\hline Staphylococcus equorum & GenBank:NR_027520 & $98.8-99.1$ & MSA & $3.0 .10^{8}$ & - \\
\hline Staphylococcus epidermidis & GenBank:NC_004461 & 98.5 & MSA & $8.10^{7}$ & - \\
\hline Facklamia tabacinasalis & GenBank:Y17820 & 99.1 & $\mathrm{BP}$ & $6.10^{5}$ & - \\
\hline Lactococcus lactis & GenBank:NC_002662 & 99.5 & MRS & $4.10^{4}$ & - \\
\hline Enterococcus devriesei & GenBank:AJ891167 & 98.2 & MRS & $1.10^{4}$ & - \\
\hline Enterococcus malodoratus & GenBank:Y18339 & 99.8 & MRS & $2.10^{3}$ & - \\
\hline Enterococcus faecalis & GenBank:AJ420803 & 99.3 & KFS & $2.10^{2}$ & - \\
\hline Enterococcus faecium & GenBank:EU547780 & 100.0 & KFS & $6.10^{1}$ & - \\
\hline
\end{tabular}

128 isolates, i.e. ca. 25 isolates per media, were analyzed by TTGE and grouped into identical TTGE profiles. A representative isolate of each profile was identified by $16 \mathrm{~S}$ rDNA sequencing. After the assignment of all isolates to a species, the percentage of each species on each of the five media was assessed. The cell count of a species was calculated by multiplying percentage and cell count determined for the corresponding media.

${ }^{2}$ Closest $16 \mathrm{~S}$ rDNA sequence in the GenBank public database http://www.ncbi.nlm.nih.gov.

${ }^{3}$ Total cell count was determined on TGYA. In addition, staphylococci were enumerated on BP agar and MSA, lactic acid bacteria on MRS agar and enterococci on KFS agar.

${ }^{4}$ Given the polymorphy in the intraspecies diversity of $B$. linens (Oberreuter et al. [52]), strain assignation to $B$. linens or the related species $B$. aurantiacum based on $16 \mathrm{~S}$ rDNA analysis only was considered not reliable.

\section{Bacterial biodiversity of cheese surface consortia by TTGE fingerprinting}

Bacterial biodiversity of consortium $\mathrm{F}$ and $\mathrm{M}$ was assessed by TTGE fingerprinting of total DNA extracts, a culture independent method (Figure 2). Both consortia were analyzed on two gels, targeting the bacterial species with high-GC and low-GC content in separate runs. TTGE fingerprints of consortia $\mathrm{F}$ and $\mathrm{M}$ were composed of 18 bands each, corresponding to 13 and 10 species, respectively. Five bands could not be assigned to a known species of the database and were therefore submitted to cloning and sequencing after excision (Table 2). High similarity was found between consortium $\mathrm{F}$ and $\mathrm{M}$ with 9 common species, i.e. Corynebacterium variabile, Microbacterium gubbeenense, an uncultured bacterium from marine sediment (Table 2), Corynebacterium casei, Brevibacterium linens, Staphylococcus equorum, Lactococcus lactis, Agrococcus casei and Alkalibacterium kapii. Consortium F showed a higher diversity than consortium $M$ with four additional species, Brachybacterium tyrofermentans, Brachybacterium sp., Marinilactibacillus psychrotolerans and Staphylococcus vitulinus. The species Brachybacterium paraconglomeratum was specific to consortium $\mathrm{M}$.

\section{Population dynamics of cheese surface consortia by cultivation methods}

Total cell counts and yeast counts were similar for all cheeses, independent of the surface flora applied to cheeses, i.e. consortium F, M or control flora OMK 704. Total cell counts increased from $1.2 \pm 0.4 \times 10^{7} \mathrm{CFU} \mathrm{cm}^{-2}$ to $1.2 \pm 0.7 \times 10^{9} \mathrm{CFU} \mathrm{cm}{ }^{-2}$ within 14 days and remained stable afterwards $\left(1.7 \pm 1.0 \times 10^{9} \mathrm{CFU} \mathrm{cm}^{-2}\right)$. Yeast counts increased from day 4 to reach $6.5 \pm 0.2 \times 10^{6} \mathrm{CFU} \mathrm{cm}^{-2}$ at day 7 and decreased afterwards by 2 to $3 \log$ until the end of ripening. Mould counts of ca. $10^{2} \mathrm{CFU} \mathrm{\textrm {cm } ^ { - 2 }}$ were measured after 3 weeks ripening on cheeses treated with consortium $\mathrm{F}$, while no moulds were detected on the cheese treated with consortium $\mathrm{M}$ or on control cheese. At the end of ripening, similar mould counts of ca. $10^{4} \mathrm{CFU} \mathrm{\textrm {cm } ^ { - 2 }}$ were measured on all cheeses. The $\mathrm{pH}$ of cheese surface increased from $5.5 \pm 0.1$ at day 4 to $6.8 \pm 0.4$ at day 7 to 10 , depending on the cheese, and was constant afterwards, with mean $\mathrm{pH}$ of $7.2 \pm 0.4$.

\section{Population dynamics of complex cheese surface consortia by TTGE fingerprinting}

Population dynamics of consortium $\mathrm{F}$ or $\mathrm{M}$ were assessed at species level by TTGE fingerprinting of total DNA extracts (Figure 3, Table 3). TTGE fingerprints of day 1 cheese depict the starter culture (Lc. lactis) as well as the composition of the smear brines. Multiple shifts in the microbial community structure of cheeses treated with complex surface consortia $\mathrm{F}$ or $\mathrm{M}$ were observed throughout ripening. The nine species common to both consortia had similar sequential development on cheese surface. Lc. lactis, used as starter culture for cheese 


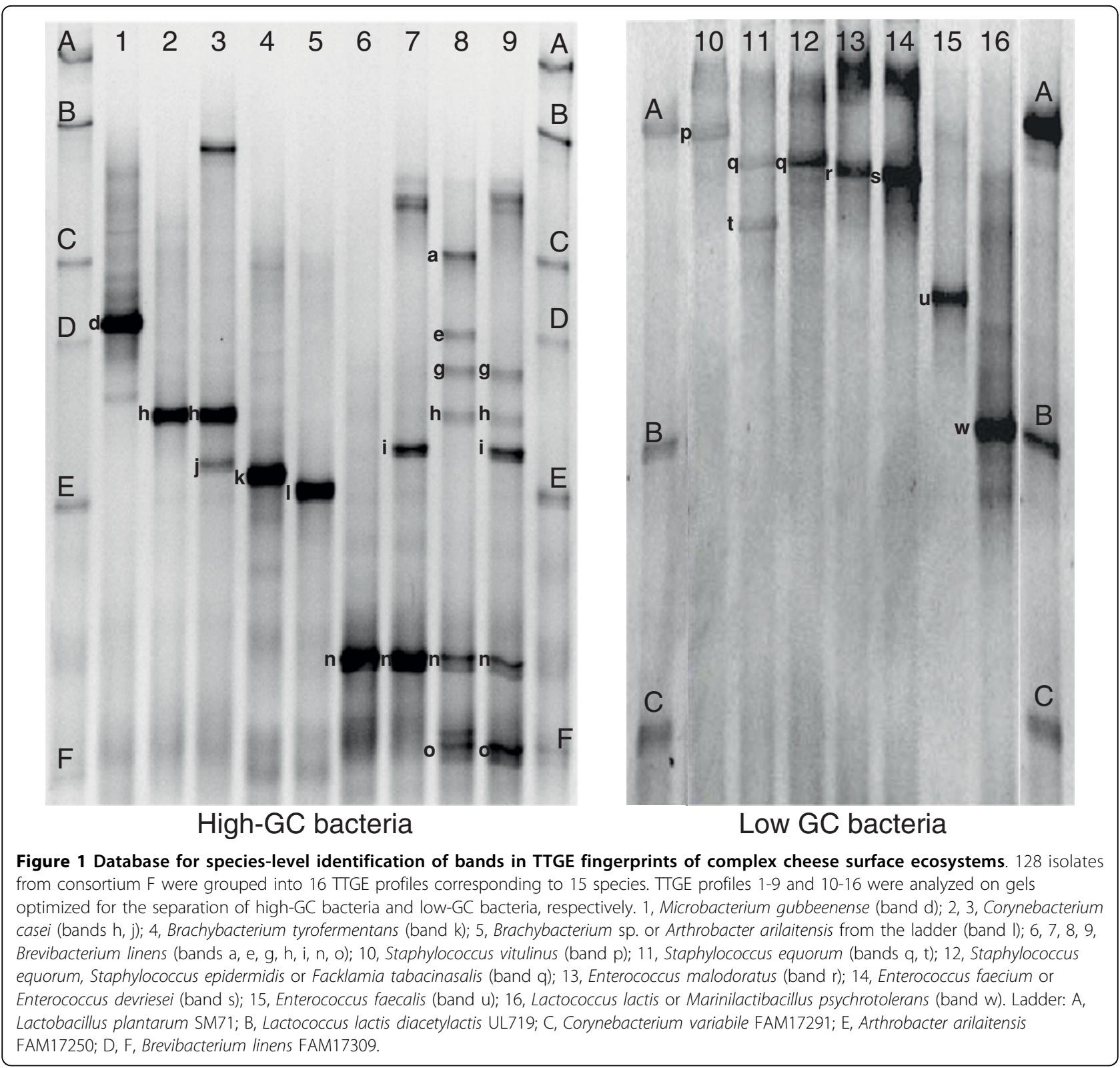

manufacture, was part of the dominant flora until day 7 and disappeared thereafter. St. equorum was the first species to colonize the surface within 7 days. Al. kapii grew on day 14 concomitant with C. casei and B. linens, followed by $C$. variabile, an uncultured bacterium from marine sediment and Mc. gubbeenense between day 14 and 37. Agrococcus casei was first detected on day 37. Other species specific to consortium F (St. vitulinus, Enterococcus sp., M. psychrotolerans, Brachybacterium sp. and Br. tyrofermentans) colonized the corresponding cheese after 7 to 21 days ripening. Both Brachybacterium species also colonized the cheese treated with consortium $\mathrm{M}$, but could only be detected after 81 days, together with the Brachybacterium species specific to consortium M (Br. paraconglomeratum). Repetition of both treatments revealed the same trends with minor differences including a growth delay (ca. 5 days) for some high-GC species and the additional development of M. psychrotolerans at day 20 on the cheese treated with consortium $\mathrm{M}$ (data not shown).

\section{Population dynamics of the defined commercial culture OMK 704 by TTGE fingerprinting}

Population dynamics of the defined commercial culture OMK 704 at species level was assessed by TTGE fingerprinting of total DNA extracts (Figure 3, Table 3). All three species of the culture OMK 704 (C. variabile, $A$. arilaitensis and $B$. linens) established themselves on 

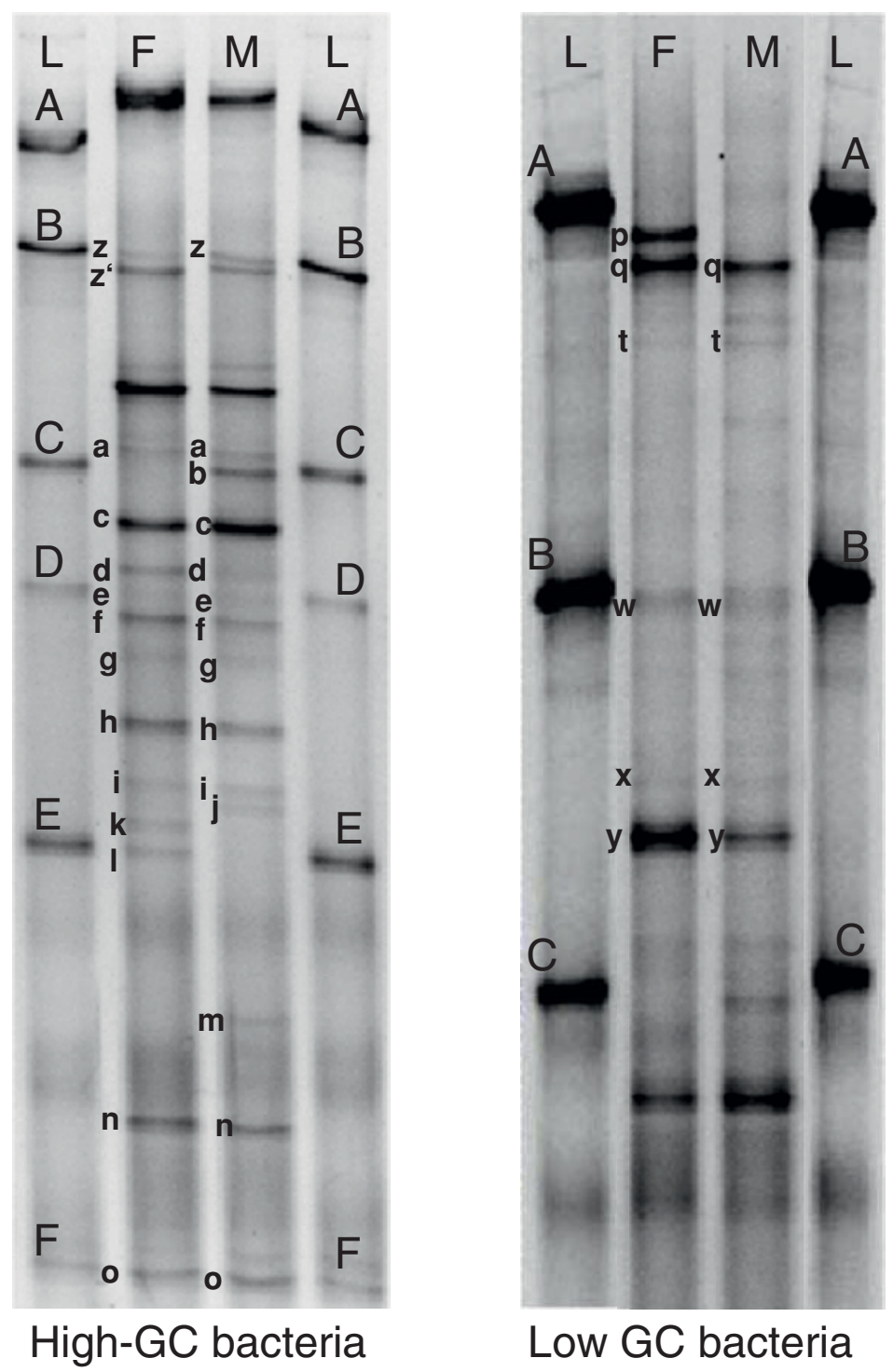

Figure 2 Biodiversity of cheese surface consortia $\mathbf{F}$ and $\mathbf{M}$ by a culture independent method. TTGE fingerprints were analyzed on two different gels (high and low GC) after total DNA extraction of cheese surface consortia. Single bands were assigned to species using the species database or by excision, cloning and sequencing $\left(^{*}\right) . b, c^{*}, C$. variabile; $d$, Mc. gubbeenense; $f^{*}$, uncultured bacterium from marine sediment; $h, j, C$. casei; k, Br. tyrofermentans; I, Brachybacterium sp.; m*, Br. paraconglomeratum; a, e, g, h, i, n, o, B. linens; p, St. vitulinus; q, St. equorum, St.

epidermidis or F. tabacinasalis; q, t, St. equorum; W, Lc. lactis or M. psychrotolerans; $x^{*}$, Ag. casei; $y^{*}$, Al. kapii; z, Lc. lactis; Z', M. psychrotolerans. L, Ladder: A, Lb. plantarum SM71; B, LC. lactis diacetylactis UL719; C, C. variabile FAM17291; E, A. arilaitensis FAM17250; D, F, B. linens FAM17309.

\section{Table 2 Identification of non-assigned TTGE bands by excision, cloning and sequencing}

\begin{tabular}{llll}
\hline Band Designation $^{1}$ & Bacterial species & Accession number $^{\mathbf{2}}$ & Similarity (\%) \\
\hline $\mathrm{c}$ & Corynebacterium variabile & GenBank:AJ783438 & 98.3 \\
$\mathrm{f}^{3}$ & uncultured bacterium from marine sediment & GenBank:FJ717185 & 97.2 \\
$\mathrm{~m}$ & Brachybacterium paraconglomeratum & GenBank:AJ415377 & 96.8 \\
$\mathrm{x}$ & Agrococcus casei & GenBank:DQ168427 & 100 \\
$\mathrm{y}$ & Alkalibacterium kapii & GenBank:AB294171 & 97.5 \\
\hline
\end{tabular}

${ }_{1}^{1}$ These designations are used to annotate bands from TTGE gels in figures 2 and 3.

${ }^{2}$ Closest 165 rDNA sequence in the GenBank public database http://www.ncbi.nlm.nih.gov.

${ }^{3}$ The $16 \mathrm{~S}$ rDNA sequence of band $\mathrm{f}$ exhibited highest similarity of $94 \%$ with Clostridiisalibacter paucivorans (GenBank: EF026082), a bacterium that belong to cluster XII of the Clostridium subphylum [53]. 


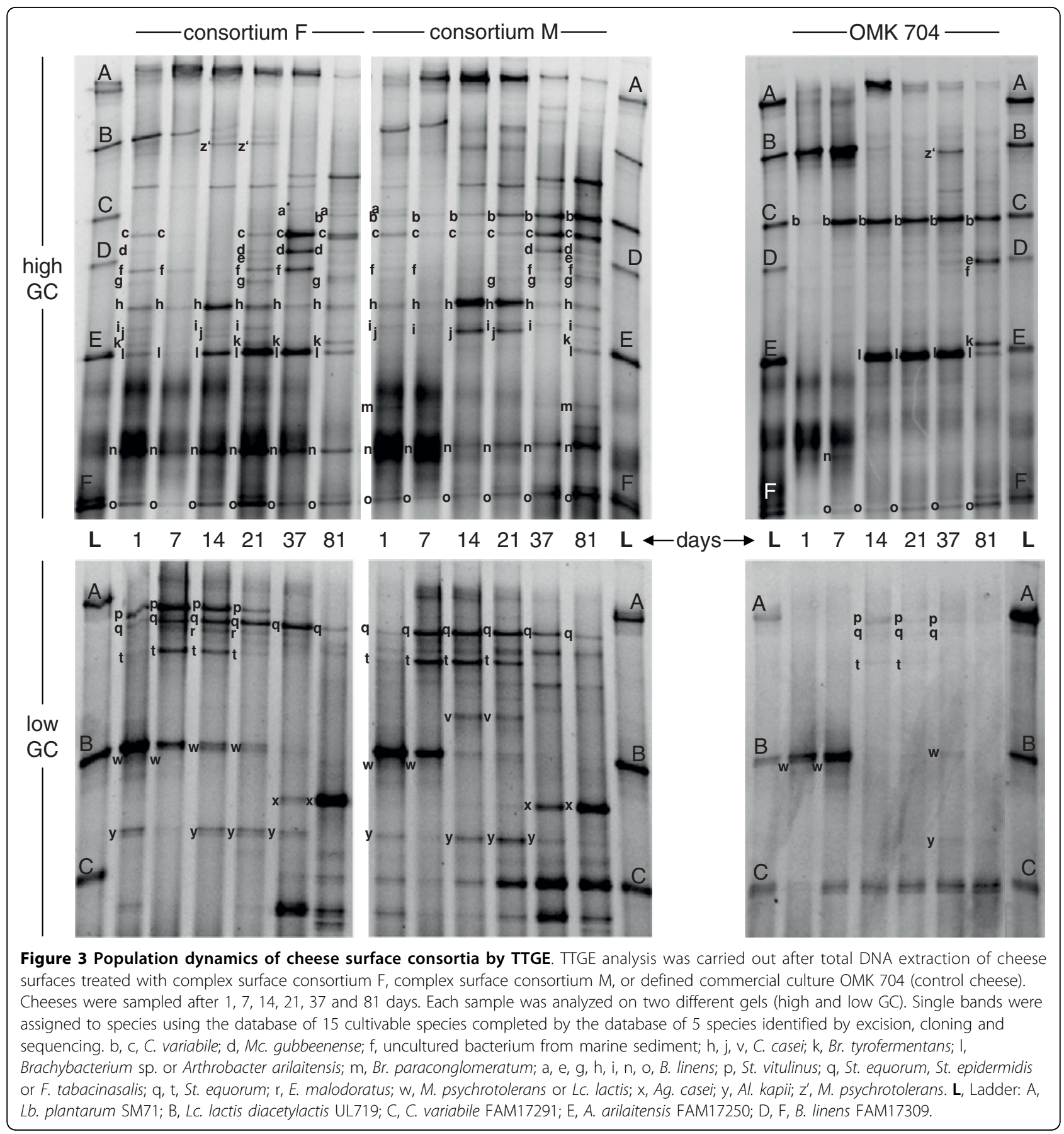

cheese surface during the first 14 days. Each of the five B. linens strains of the culture OMK 704 exhibited a distinguishable strain-specific TTGE profile (data not shown). The profile of $B$. linens FAM17309 (Bands e, o; Figure 3) was detected in the TTGE fingerprint of day 81 cheese, showing that this strain predominated over other B. linens strains at the end of ripening. Additional species not deliberately applied on the cheese colonized the cheese surface along ripening. Two staphylococci species (St. vitulinus; St. equorum) appeared on day 14 as well as M. psychrotolerans and Al. kapii on day 37 . $B r$. tyrofermentans and an uncultured bacterium from marine sediment completed the high GC community at day 81 . Repetition of the treatment revealed the same trends regarding the three defined species. However, the development of non-deliberately applied species was different in the repetition. Three additional species colonized the cheese, i.e. Enterococcus sp., C. casei, Ag. casei, 
Table 3 Population dynamics of cheese surface consortia by TTGE ${ }^{1}$

\begin{tabular}{|c|c|c|c|c|c|c|c|c|c|c|c|c|c|c|c|c|c|c|c|}
\hline \multirow[t]{2}{*}{ Bacterial species detected with TTGE } & \multirow[t]{2}{*}{$\begin{array}{l}\text { Band } \\
\text { designation }\end{array}$} & \multicolumn{6}{|c|}{$\begin{array}{l}\text { Consortium } F \\
\text { (ripening day) }\end{array}$} & \multicolumn{6}{|c|}{$\begin{array}{l}\text { Consortium } M \\
\text { (ripening day) }\end{array}$} & \multicolumn{6}{|c|}{$\begin{array}{l}\text { OMK } 704 \text { (ripening } \\
\text { day) }\end{array}$} \\
\hline & & 1 & 7 & 14 & 21 & 37 & 81 & 1 & 7 & 14 & 21 & 37 & 81 & 1 & 7 & 14 & 21 & 37 & 81 \\
\hline Ag. Casei & $x$ & & & & & + & $\mathrm{d}$ & & & & + & $\mathrm{d}$. & & & & & & & \\
\hline Al. kapii & y & d. & & + & d. & d. & & d. & & + & $\mathrm{d}$ & d. & & & & & & + & \\
\hline Br. paraconglomeratum & $\mathrm{m}$ & & & & & & & d. & & & & & + & & & & & & \\
\hline $\begin{array}{l}\text { Brachybacterium sp., or } \\
\text { A. arilaitensis }\end{array}$ & । & d. & d. & + & d. & d. & $\mathrm{d}$ & & & & & & + & & & + & d. & d. & d. \\
\hline Br. tyrofermentans & k & $\mathrm{d}$. & & & + & d. & $\mathrm{d}$ & & & & & & + & & & & & & + \\
\hline B. linens & $a, e, g, h, i, n, o$ & d. & d. & + & d. & $\mathrm{d}$ & $\mathrm{d}$ & d. & d. & + & $\mathrm{d}$ & d. & d. & & + & d. & d. & d. & d. \\
\hline C. casei & $h, j, v$ & d. & d. & + & d. & d. & $\mathrm{d}$ & d. & d. & + & $\mathrm{d}$ & d. & d. & & & & & & \\
\hline C. variabile & $b, c$ & d. & d. & & + & d. & $\mathrm{d}$ & d. & d. & + & $\mathrm{d}$ & d. & d. & d. & + & d. & d. & d. & d. \\
\hline E. malodoratus & r & & & + & d. & & & & & & & & & & & & & & \\
\hline Lc. lactis & w (without z') & $\mathrm{d}$. & d. & & & & & d. & d. & & & & & d. & d. & & & & \\
\hline M. psychrotolerans & $w$ and $z^{\prime}$ & & & + & d. & & & & & & & & & & & & & + & \\
\hline Mc. gubbeenense & $d$ & d. & & & + & $\mathrm{d}$ & d. & & & & & + & d. & & & & & & \\
\hline $\begin{array}{l}\text { St. equorum, St. epidermidis, or } \\
\text { F. tabacinasalis }\end{array}$ & $q$ & d. & + & d. & d. & d. & $\mathrm{d}$ & d. & + & d. & $\mathrm{d}$ & d. & d. & & & + & d. & d. & \\
\hline St. equorum & $\mathrm{q}$ and $\mathrm{t}$ & d. & + & d. & d. & & & d. & + & $\mathrm{d}$. & $\mathrm{d}$ & & & & & & d. & & \\
\hline St. vitulinus & $p$ & d. & + & d. & d. & & & & & & & & & & & + & d. & d. & \\
\hline $\begin{array}{l}\text { uncultured bacterium from marine } \\
\text { sediment }\end{array}$ & $f$ & d. & d. & & + & $\mathrm{d}$ & & d. & d. & & & + & $\mathrm{d}$ & & & & & & + \\
\hline
\end{tabular}

${ }^{1}$ The letter (d.) indicates sampling times where a given species was detected in the TTGE gel. The symbol (+) indicates growth of a species in the smear. Growth was assumed in two cases, i.e. when a band was detected at a sampling time, while absent from the previous sampling time, or when the intensity of the detected band increased, compared to the previous sampling time (valid only at day 7 and 14, i.e. for a 1 log-increase of the total cell count).

${ }^{2}$ The same letter code as for band designation in Figure 3 was used.

while Br. tyrofermentans could not be detected (data not shown).

In situ inhibition of Listeria by complex surface consortia Raclette cheeses were artificially contaminated with 4 strains of Listeria innocua on day 7 and 8, i.e. when yeasts on cheese surface had reached high counts of 6.5 $\pm 0.2 \times 10^{6} \mathrm{CFU} \mathrm{cm^{-2 }}$. From the amount added to the smear brine $\left(5 \times 10^{3} \mathrm{CFU} \mathrm{ml}^{-1}\right)$, Listeria counts of $1.4 \pm$ $0.9 \times 10^{1} \mathrm{CFU} \mathrm{cm}^{-2}$ (first trial) and of $1.0 \pm 0.6 \times 10^{2}$ $\mathrm{CFU} \mathrm{cm}$ (repetition) were recovered from the surface immediately after contamination. Listeria development was strongly affected by the surface flora applied for ripening. A decrease of Listeria counts below the detection limit of the method $\left(<3 \mathrm{CFU} \mathrm{cm} \mathrm{cm}^{-2}\right)$ was observed for cheeses treated with complex consortia F or M supplemented with Debaryomyces hansenii FAM14334 (Figure 4). Listeria could be recovered from cheese surface $\left(\sim 2000 \mathrm{~cm}^{2}\right)$ with an enrichment procedure at the end of ripening (60 to 80 days), for both consortia. In contrast, Listeria counts on control cheeses treated with the commercial culture OMK 704 increased to ca. $10^{5} \mathrm{CFU}$ $\mathrm{cm}^{-2}$ after one month (Figure 4).

\section{Discussion}

To our knowledge, this work describes the first dynamic study of naturally developing anti-listerial cheese surface consortia. The monitoring of two complex consortia obtained from industrial productions was carried out with TTGE, a culture independent fingerprinting technique which enabled species-level detection of high-GC and low-GC bacteria in separate runs.

Previous studies reported a broad range of biodiversity in smear consortia, with 2 to 15 bacterial species detected $[2,5,22,23]$. High bacterial diversity was observed in consortium F, with 13 species detected at dominant level by culture independent analysis. The cultivation approach detected only 9 of the 13 species present at dominant level in consortium $\mathrm{F}$, but enabled detection of 6 additional species present at subdominant level. TTGE is a semiquantitative approach with limited sensitivity compared to the cultivation approach. However, as fingerprinting technique, TTGE enabled to overcome the arbitrary selection exercised on the flora by the cultivation step, giving a more complete view of biodiversity at dominant level. The combined use of both approaches led to a detailed knowledge of biodiversity in cheese smear flora, as already observed by Feurer $e t$ $a l$. and Mounier et al. $[5,24]$. The identification strategy used in the present study for the cultivation approach, i. e. all cultivable isolates grouped by TTGE profiles and subsequent sequencing, enabled the detection of intraspecies diversity differentiation in 3 dominant species. This strategy greatly simplified the identification of 


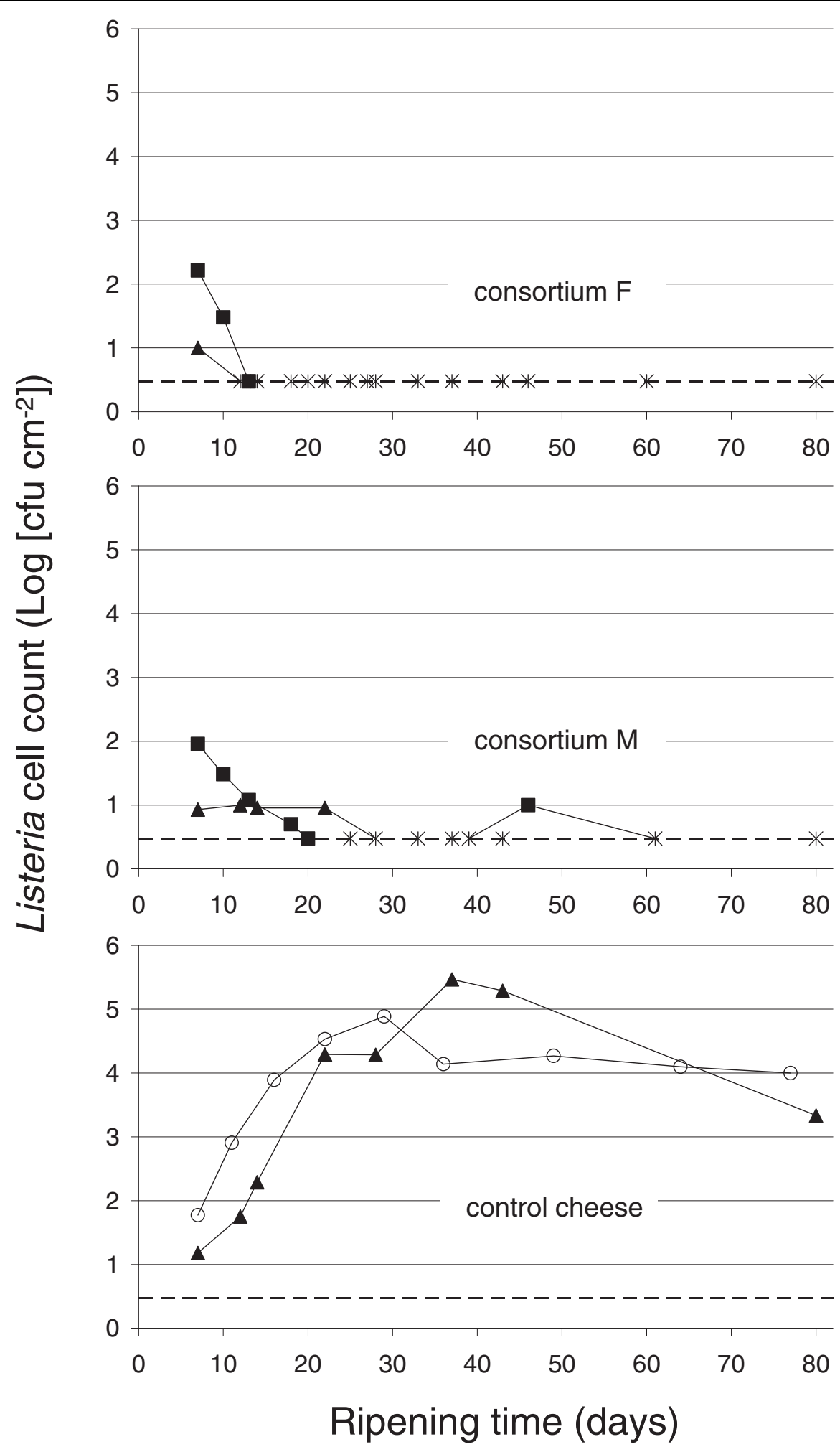

Figure 4 In situ inhibition of Listeria on cheese surface by complex consortia. Cheese surfaces were treated with smear brines (3.3\% (W/v) $\mathrm{NaCl}$ ), inoculated with either consortium F, consortium M or the defined commercial culture OMK 704 (control cheese). Two independent experiments were carried out for each treatment. Different symbols indicate different commercial cheese production. Smear brines were

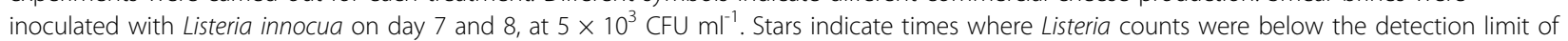
the enumeration method ( $<3 \mathrm{CFU} \mathrm{cm}^{-2}$; dashed line). 
bands in the TTGE fingerprints of complex consortia corresponding to intraspecies variability. Consortium $\mathrm{M}$ displayed slightly less diversity than F with 10 species detected at the dominant level by culture independent analysis.

A total of 20 species were detected in consortia $\mathrm{F}$ and $\mathrm{M}$, including eight coryneform bacteria. $C$. variabile, $C$. casei, B. linens and Mc. gubbeenense are common ripening microorganisms of smear cheeses detected on soft cheeses [5,9] and semi-hard cheeses [2,8,23]. Br. tyrofermentans was first isolated from Gruyère cheese [25] and was recently shown to colonize the surface of soft cheeses [5,9]. To our knowledge, this is the first time that Br. paraconglomeratum has been detected in cheese although this species has been previously isolated from milk [26]. Agrococcus casei was first isolated from Gubbeen, an Irish semi-hard cheese [2]. Three Staphylococcus species were isolated in addition to coryneforms. St. equorum is common on smear cheeses [6,8,27-29] while St. vitulinus was only isolated by Irlinger et al. [27] from French cheeses. St. epidermidis, a human skin inhabitant, was detected on various Irish semi-hard cheeses $[2,8]$. Two Gram-positive marine lactic acid bacteria (LAB) and an uncultured bacterium from marine sediment were also part of the dominant flora. M. psychrotolerans has been detected in the smear of soft cheeses from Germany and France [5,9]. Alkalibacterium sp. was found to be present in many European cheeses including Tilsiter, a semi-hard smear cheese [10]. We also identified potentially undesirable species of enterococci in the subdominant flora of consortium F. Enterococci have a controversial status in the dairy industry. They are considered naturally occurring ripening organisms for artisan Mediterranean cheese [30], but also appear as emerging pathogens due to the virulence factors they tend to harbor [31]. To our knowledge, this study is the first report of the presence of Facklamia sp. in cheese. F. tabacinasalis was first isolated from powdered tobacco by Collins et al. [32] and has recently been detected in raw milk by Delbès et al. [33] in a French farm producing Saint-Nectaire cheese and by Hantsis-Zacharov and Halpern [34] in a farm from northern Israel equipped with modern automated milking facilities. The presence of $F$. tabacinasalis on the surface of smear cheese may constitute a health hazard, as this species was shown to be $\alpha$-haemolytic on horse blood [32]. Moreover, from six Facklamia species described to date, four were isolated from human clinical specimen [35].

We observed highly similar microbial community structures of consortia $\mathrm{F}$ and $\mathrm{M}$, with 9 species being common to both consortia at dominant level, despite different ripening procedures. High interbatch diversity was described by Rea et al. [8] in a single cheese ripening facility of Gubbeen, an Irish semi-hard smear cheese, over 8 years production, which may be related to a lack of humidity and temperature control during ripening of Gubbeen cheese. In the present study, the production of Swiss Raclette type cheese with defined production and ripening parameters led to the development of a similar flora in two distinct dairies. The source of this highly diverse flora remains unidentified but possible sources could be the brine bath, skin of the workers or wooden shelves, as shown by Mounier et al. [36] for Gubbeen cheese.

The high biodiversity is particularly surprising in the case of dairy F, where the smear brine is freshly prepared prior to each smearing and inoculated with a defined ripening culture of only 3 bacterial species. Moreover, the smear brine is applied by a cheese ripening robot that smears the young cheeses first. However, the microflora of the brine bath is not controlled and might be one of the major sources. In particular, the brine bath $(18-22 \%(\mathrm{w} / \mathrm{v}) \mathrm{NaCl})$ could be suitable to maintain the two halophilic and alkaliphilic marine $\mathrm{LAB}$ detected in consortium F, as some strains of M. psychrotolerans and Al. kapii were shown to grow at salt concentration as high as $21 \%(\mathrm{w} / \mathrm{v})$ by Ishikawa et al. $[37,38]$.

Dynamic studies of consortia $\mathrm{F}$ and $\mathrm{M}$ inoculated at same cell counts on cheese surface revealed a similar sequential development of nine bacterial species, i.e. $L c$. lactis, St. equorum, Al. kapii, C. casei, B. linens, C. variabile, an uncultured bacterium from marine sediment, Mc. gubbeenense and Ag. casei. The development of this microbial community prevented growth of Listeria innocua, inoculated at $5 \times 10^{3} \mathrm{CFU} \mathrm{ml}^{-1}$ smear brine on cheeses at day 7 and 8 , over 60 to 80 days ripening. Contamination at day 7 and 8 , i.e. when yeasts reached their highest density, provided optimal growth conditions for Listeria, as shown by the rapid Listeria growth on control cheese. Strong antilisterial activities were shown in this unfavorable condition for consortia $\mathrm{F}$ and M. Antilisterial activities of complex undefined cheese surface consortia were already observed in previous studies [9,15]. Maoz et al. [9] reported a total inhibition of L. monocytogenens during 40 days ripening of a soft smear cheese with an initial contamination level of $1.6 \times$

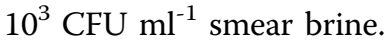

The surface of smear cheese contains a limited range of substrates supporting growth of microorganisms, mainly lactose and lactate. Lactose is mostly metabolized by LAB during curd acidification and initial ripening. The residual lactose can be metabolized on the cheese surface by yeasts during the first days of ripening, as shown for soft cheeses by Leclercq-Perlat et al. [39]. Lactate metabolized by yeasts into $\mathrm{CO}_{2}$ and $\mathrm{H}_{2} \mathrm{O}$ leads to deacidification of the cheese surface [40]. As a result, 
lactate continuously diffuses from the core to the surface of the cheese. Lactate can be totally consumed by surface microorganisms in soft cheeses [41]. Several smear bacterial species, i.e. Brevibacterium aurantiacum, C. casei, C. variabile, Mc. gubbeenense and St. saprophyticus, were shown to use lactate and casaminoacids for growth [42]. In contrast, Listeria sp. can only use a limited range of carbon sources for growth, including glucose, glycerol, fructose and mannose, while no growth occurs on lactate or casaminoacids [43-46]. Premaratne et al. [44] showed that Listeria monocytogenes may utilize alternative carbon sources, such as N-acetylglucosamine and $\mathrm{N}$-acetylmuramic acid, which are major components of bacterial and fungal cell walls [44,47]. In addition, the yeast cell wall contains a mannan glycopeptide with mannose [48], a sugar metabolized by Listeria sp. Listeria growth on smear cheese can therefore be limited by a low availability of carbon source and stimulated by components of smear microorganisms.

Marine LAB ferment glucose into lactate and assimilate mannose [37,38]. Ishikawa et al. [38] reported that Al. kapii can utilize a fairly limited range of carbon sources. In the present study, M. psychrotolerans and/or Al. kapii established early on cheeses treated by complex consortia, i.e. between day 14 and day 20. We believe competition for nutrients between marine LAB and Listeria sp. may be involved in Listeria inhibition in the smear since the development of $M$. psychrotolerans and Al. kapii occurred simultaneously with the decrease of Listeria counts for both cheeses treated with consortium F (first trial and repetition) and for one cheese treated with consortium $\mathrm{M}$ (repetition). In addition, Listeria growth on control cheese stopped when $M$. psychrotolerans and $A l$. kapii were first detected in the smear, i.e. on day 37. Hain et al. [49] reported a microarray experiment conducted with the antilisterial complex smear consortium described by Maoz et al. [9]. Genes involved in energy supply were mostly up-regulated after 4 hours of contact between Listeria monocytogenes and the consortium, suggesting that Listeria had entered a state of starvation. While Maoz et al. [9] detected M. psychrotolerans in the aforesaid smear consortium by cultivation methods, they may have overlooked the presence of $A l$. kapii or related species.

\section{Conclusions}

This work reports the first study of population dynamics of antilisterial cheese surface consortia. Dynamics of two consortia obtained from industrial productions revealed highly similar, with the sequential development of 9 common species, whereas development of both consortia inhibited Listeria growth over the whole ripening period. Next to common cheese surface bacteria, the two consortia contained marine lactic acid bacteria (LAB) that developed early in ripening, shortly after the growth of staphylococci and concomitant with a decrease in Listeria cell counts. Competition for nutrients between marine LAB and Listeria sp. could be involved in the observed inhibition. Temporal temperature gradient gel electrophoresis revealed decisive to detect all marine bacteria present at dominant level in the smear, as only one of three species was detected by the culture dependent approach. Further cheese ripening experiments are needed to investigate the potential contribution of marine LAB to antilisterial activity.

\section{Methods}

\section{Collection of cheese surface consortia and microbial cultures}

Cheese surface consortia were collected from two Swiss cheese manufacturers of Raclette type cheese made of pasteurized milk. Consortium F was collected from a 4weeks old cheese produced with a defined surface ripening culture in industrial-scale dairy $\mathrm{F}$. The surface ripening culture was composed of OFR9 (Danisco A/S, Copenhagen, Denmark), containing Brevibacterium linens, Brevibacterium casei as well as three yeasts, and OMK 703 (Research Station Agroscope LiebefeldPosieux ALP, Bern, Switzerland), containing Brevibacterium linens, Arthrobacter arilaitensis as well as two yeasts. Consortium $M$ was collected from a 6-weeks old cheese in small-scale dairy $M$, where the cheeses were treated with old-young smearing, with a smear brine derived from Gruyère type cheese. Surface consortia were scraped off the cheese $\left(\sim 2000 \mathrm{~cm}^{2} ; \sim 10 \mathrm{~g}\right)$, homogenized in a stomacher in $100 \mathrm{ml} \mathrm{3.3 \% (w/v)} \mathrm{NaCl}$ for 4 min and stored at $4{ }^{\circ} \mathrm{C}$ until further use but not longer than 30 days. Long-term storage (up to 7 months) was carried out by addition of $20 \%$ glycerol and freezing at $-30^{\circ} \mathrm{C}$. The commercial surface culture OMK 704 (ALP, Bern, Switzerland), used as control in cheese ripening experiments, contained one yeast (Debaryomyces hansenii FAM14334, ALP culture collection), five Brevibacterium linens, five Corynebacterium variabile, and one Arthrobacter arilaitensis strains. Each strain of the commercial culture was provided in a liquid form and stored at $4^{\circ} \mathrm{C}$ (short term) or at $-30^{\circ} \mathrm{C}$ with addition of $20 \%$ glycerol (long term). For safety reasons, non pathogenic Listeria strains were used as a model for L. monocytogenes in cheese ripening experiments. Listeria innocua 80945-8, 81000-1, 81003-3, and 81587-4 (Laboratory of Food Biotechnology, ETH Zurich, Zurich, Switzerland) had previously been isolated from smears by ALP (Bern, Switzerland). Listeria strains were grown in tryptic soy broth (Oxoid, Pratteln, Switzerland) supplemented with $0.6 \%(\mathrm{w} / \mathrm{v})$ yeast extract (Merck, Dietikon, Switzerland) at $30^{\circ} \mathrm{C}$ for $14 \mathrm{~h}$. 


\section{Cell enumeration of cheese surface consortia}

Total cell counts were determined on TGYA (Tryptic Glucose Yeast Agar, Biolife, Milano, Italy) supplemented with $1 \%(\mathrm{w} / \mathrm{v})$ casein peptone (BBL, Heidelberg, Germany) after incubation at $30^{\circ} \mathrm{C}$ for 3 days, followed by incubation at room temperature with daylight exposure for another 7 days. Staphylococci were counted on BP agar (Baird Parker RPF agar; BioMérieux, Geneva, Switzerland) and MSA (Mannitol Salt Agar, Oxoid, Pratteln, Switzerland) after incubation at $37^{\circ} \mathrm{C}$ for 6 days. Yeast counts and mould counts were both determined on PY agar (Phytone Yeast extract agar, BBL, Heidelberg, Germany) incubated at $30^{\circ} \mathrm{C}$. The plates were examined after 3 days for yeasts and after 6 days for moulds. Enterococci were determined on KFS agar (KF Streptococcus agar, Becton Dickinson AG, Allschwil, Switzerland) incubated at $42^{\circ} \mathrm{C}$ for 3 days, and Listeria on Palcam agar (Oxoid, Pratteln, Switzerland) incubated at $37^{\circ} \mathrm{C}$ for 2 days, all under aerobic conditions. Lactic acid bacteria were counted on MRS agar with Tween 80 (De Man et al., 1960, Biolife, Milano, Italy) incubated at $37^{\circ}$ $\mathrm{C}$ for 6 days, under anaerobic conditions which were generated using GENbox anaerobic systems (Biomérieux, Geneva, Switzerland). At the end of ripening, the presence or absence of Listeria was assessed using a three-step enrichment procedure that was previously validated against the reference method ISO 11290-1 for use on smear samples by ALP (Bern, Switzerland). $10 \mathrm{~g}$ $\left(\sim 2000 \mathrm{~cm}^{2}\right)$ of smear were homogenized in $90 \mathrm{~g}$ tryptic soy broth supplemented with $0.6 \%(\mathrm{w} / \mathrm{v})$ yeast extract, $0.02 \%(\mathrm{w} / \mathrm{v})$ Delvocid $^{\circledR}$ (DSM, Heerlen, Netherlands), $0.001 \%(\mathrm{w} / \mathrm{v})$ acriflavin (Fluka, Buchs, Switzerland), and $0.004 \%(\mathrm{w} / \mathrm{v})$ nalidixic acid (Fluka, Buchs, Switzerland) for 4 min using a Stomacher and incubated at $30^{\circ} \mathrm{C}$ for $24 \mathrm{~h}$. After this step, $1 \%(\mathrm{v} / \mathrm{v})$ of enriched sample was inoculated to supplemented tryptic soy broth and incubated again at $30^{\circ} \mathrm{C}$ for $24 \mathrm{~h}$. Presence or absence of Listeria was then checked by streaking a loopful of the second enrichment media on ALOA agar (Biolife, Pero, Italy) that was incubated at $37^{\circ} \mathrm{C}$ for $24 \mathrm{~h}$.

\section{DNA extraction of complex consortia and single isolates}

Total DNA extraction of cheese surface consortia was carried out with $1 \mathrm{ml}$ homogenate containing $10^{7}$ to $10^{9}$ $\mathrm{CFU} \mathrm{m} \mathrm{m}^{-1}$ that was centrifuged at $18^{\prime} 000 \times \mathrm{g}$ for $5 \mathrm{~min}$. The resulting pellet was stored at $-20^{\circ} \mathrm{C}$ until further use. The DNA extraction protocol was modified from Chavagnat et al. [50]. The frozen pellet was resuspended in $1 \mathrm{ml} 0.1 \mathrm{M} \mathrm{NaOH}$, incubated at room temperature for $15 \mathrm{~min}$ and centrifuged at $18^{\prime} 000 \times \mathrm{g}$ for $5 \mathrm{~min}$. The pellet was resuspended in $1 \mathrm{ml}$ TES buffer $(10 \mathrm{mM}$ EDTA, 0.1. $\mathrm{M}$ tris(hydroxymethyl)-aminomethane, 25\% $(\mathrm{w} / \mathrm{v})$ saccharose) containing $0.25 \%(\mathrm{w} / \mathrm{v})$ lysozyme (50000 U mg ${ }^{-1}$, Merck, Dietikon, Switzerland), incubated at $37^{\circ} \mathrm{C}$ for $1 \mathrm{~h}$, and centrifuged at $18^{\prime} 000 \times \mathrm{g}$ for $5 \mathrm{~min}$. The pellet was resuspended in $190 \mu \mathrm{l} \mathrm{G2}$ Buffer (EZ1 DNA Tissue Kit, Qiagen, Basel, Switzerland) and $10 \mu \mathrm{l}$ proteinase K (EZ1 DNA Tissue Kit; Qiagen, Basel, Switzerland) were added. This suspension was incubated at $56^{\circ} \mathrm{C}$ for $1 \mathrm{~h}$ after which DNA was further purified by BioRobot $^{\circledR}$ EZ1 (Qiagen, Basel, Switzerland) and analyzed by TTGE, as described below.

DNA extraction of single isolates was carried out by dissolving one colony of a pure culture in $0.2 \mathrm{ml}$ tris- $\mathrm{K}$ buffer (0.01 M tris(hydroxymethyl)-aminomethane (Merck, Dietikon, Switzerland)) containing $0.5 \mu \mathrm{l} \mathrm{ml}^{-1}$ Tween 20 (Fluka, Buchs, Switzerland) and $0.24 \mathrm{mg} \mathrm{ml}^{-1}$ proteinase K (Sigma-Aldrich, St. Louis, USA). This suspension was first heated at $60^{\circ} \mathrm{C}$ for $1 \mathrm{~h}$ followed by $95^{\circ}$ $\mathrm{C}$ for $15 \mathrm{~min}$, and centrifuged at $10^{\prime} 000 \times \mathrm{g}$ for $5 \mathrm{~min}$ resulting in a DNA containing supernatant that was further analyzed by TTGE.

\section{Temporal temperature gradient gel electrophoresis (TTGE)}

PCR amplification of the V3 region of the $16 \mathrm{~S}$ rDNA ( $200 \mathrm{bp}$ ) was performed according to Ogier et al. [12] using a Biometra T-Personal thermocycler (Biometra, Göttingen, Germany) with direct amplification using primers HDA1-GC and HDA2 (Microsynth, Balgach, Switzerland) and $\sim 100 \mathrm{ng}$ of bacterial DNA. Ten $\mu \mathrm{l}$ of PCR products were separated on a $2 \%(\mathrm{w} / \mathrm{v})$ agarose gel to check successful amplification with a molecular weight standard of TriDye 100 bp DNA Ladder (BioConcept, Allschwil, Switzerland). TTGE analysis was carried out as described by Ogier et al. [12] with the following modifications. The electrophoresis was run in $1.5 \times$ TAE buffer (1.5 mM EDTA, $60 \mathrm{mM}$ tris(hydroxymethyl)-aminomethane, $60 \mathrm{mM}$ acetic acid) at $65 \mathrm{~V}$ for $16 \mathrm{~h}$, with a temperature ramp of $0.3^{\circ} \mathrm{C} \mathrm{h}^{-1}$ from 66 to $70^{\circ} \mathrm{C}$. The gel concentrations were optimized to enable visualization in separate runs of high-GC bacteria ( $8 \mathrm{M}$ urea; $8.5 \%$ (w/v) acrylamide (37.5:1)) and low-GC bacteria (7 M urea; $8 \%$ $(\mathrm{w} / \mathrm{v})$ acrylamide $(37.5: 1))$ by empirical approach using a ladder of dairy bacteria harboring a wide range of GCcontents (from $49 \%$ for Lactobacillus plantarum to $60 \%$ for Propionibacterium sp.). Volumes of $20 \mu \mathrm{l}$ (isolates) or $30 \mu \mathrm{l}$ (complex consortia) of PCR products were mixed with $20 \mu \mathrm{l}$ loading dye $(0.25 \%$ (w/v) Orange G, 50\% (w/v) sucrose; Fluka, Buchs, Switzerland) and loaded in each well. The detection limit of the method proved similar to Ogier et al. [12], with detection of bacterial species accounting for at least $1 \%$ of the total DNA amount.

\section{Identification of single isolates by partial sequencing of 16S rDNA}

Groups of isolates with identical TTGE profiles were formed and a representative isolate of each group was 
selected for further $16 \mathrm{~S}$ rDNA sequencing analyses. A 1400-bp fragment of the $16 \mathrm{~S}$ rDNA was amplified with universal primers 16SUNI-L and 16SUNI-R [51]. The $50-\mu l$ reaction mixture contained $\sim 20$ ng DNA (NanoDrop ND-100, Witec AG, Littau, Switzerland), $2.5 \mathrm{U}$ of Taq DNA polymerase (Euroclone, Pero, Italy), $0.4 \mu \mathrm{M}$ of each primer (Microsynth, Balgach, Switzerland), 200 $\mu \mathrm{M}$ of each deoxynucleoside triphosphate (Amersham Biosciences, Otelfingen, Switzerland), and the reaction buffer (Euroclone, Pero, Italy) consisting of $10 \mathrm{mM}$ Tris- $\mathrm{HCl}, 50 \mathrm{mM} \mathrm{KCl}$, and $1.5 \mathrm{mM} \mathrm{MgCl}_{2}$. The amplification was performed in a Biometra T-Personal thermocycler (Biometra, Göttingen, Germany) with the following temperature profile: $94^{\circ} \mathrm{C}$ for $3 \mathrm{~min}, 35$ cycles of $94^{\circ} \mathrm{C}$ for $30 \mathrm{~s}, 54^{\circ} \mathrm{C}$ for $30 \mathrm{~s}, 72^{\circ} \mathrm{C}$ for $60 \mathrm{~s}$, and a final annealing at $72^{\circ} \mathrm{C}$ for $7 \mathrm{~min}$. Amplified DNA was purified using the GFX-PCR DNA Purification Kit (GE Healthcare Biosciences, Otelfingen, Switzerland). Partial sequencing was carried out with primer 16SUNI-L and the BigDye ${ }^{\odot}$ Terminator v1.1 cycle sequencing kit (Applied Biosystems, Rotkreuz, Switzerland) and analyzed in an ABI Prism 310 genetic analyzer (Applied Biosystems, Rotkreuz, Switzerland). Species identification was obtained by matching the obtained partial sequence (500 to $900 \mathrm{bp}$ ) to deposited sequences in the GenBank public database using the BLAST program.

\section{Identification of TTGE bands by partial sequencing of the 16S rDNA}

Bands of the complex TTGE fingerprints that could not be identified by comparison with the database were excised, cloned and sequenced as described by Ogier et al. [12]. The eluted DNA was amplified by PCR using primers HDA1 and HDA2 (Microsynth, Balgach, Switzerland). PCR products were purified using the GFXPCR DNA Purification Kit (GE Healthcare Biosciences, Otelfingen, Switzerland), ligated into pGEM ${ }^{\circledR}$-T Easy vector (Promega, Dübendorf, Switzerland) and transformed into Escherichia coli (Subcloning Efficiency ${ }^{\text {тм }}$ $\mathrm{DH}^{\mathrm{mi}}$ Competent Cells, Invitrogen, Basel, Switzerland). After plasmid purification, the insert was amplified by PCR with primers HDA1-GC and HDA2. The PCR product was analyzed by TTGE to confirm its position in the gel and sequenced from both sides with primers HDA1 and HDA2. The sequence obtained ( 200 bp) was matched to deposited sequences in the GenBank public database.

\section{Cheese ripening experiments}

Raclette type cheeses $\left(\sim 6 \mathrm{~kg} ; 2000 \mathrm{~cm}^{2}\right)$ produced from pasteurized milk in dairy $\mathrm{F}$ were taken immediately after brining. A water content of $44.9 \%(\mathrm{w} / \mathrm{w})$ and salt content of $1.8 \%(\mathrm{w} / \mathrm{w})$ were measured in a $24 \mathrm{~h}$-old cheese from the production batch, by gravimetric analysis (ISO
5534/IDF 4:2004) and by potentiometric titration (IDF Standard 88A:1988), respectively. Cheeses were ripened in a pilot plant cheese cellar with controlled temperature at $11^{\circ} \mathrm{C}$ and relative humidity at $95 \%$ for 2 to 3 months. Cheeses were smeared daily until day 15 and twice a week thereafter, using $20 \mathrm{ml}$ smear brine $(3.3 \%$ $(\mathrm{w} / \mathrm{v}) \mathrm{NaCl}$ ) per cheese side. Three different treatments were applied on cheeses and two independent experiments were carried out for each treatment. Cheeses were treated with $20 \mathrm{ml}$ of smear brines inoculated with $5 \times 10^{8} \mathrm{CFU} \mathrm{ml} \mathrm{m}^{-1}$ of either: consortium $\mathrm{F}$, consortium $\mathrm{M}$ or the commercial culture OMK 704. In addition, 1 $\times 10^{7} \mathrm{CFU} \mathrm{ml}{ }^{-1}$ of the yeast strain Debaryomyces hansenii FAM14334 were inoculated in all smear brines. Smear brines were prepared fresh before each smearing with the following protocol. The appropriate amounts of consortium or defined culture and yeast were added in a $50 \mathrm{ml}$ centrifugation tube and the volume was adjusted to $20 \mathrm{ml}$ by addition of $3.3 \%(\mathrm{w} / \mathrm{v}) \mathrm{NaCl}$. Tubes were then centrifuged at 5 '000 $\times \mathrm{g}$ for $15 \mathrm{~min}$, and the pellet was resuspended in $20 \mathrm{ml}$ of fresh $3.3 \%(\mathrm{w} / \mathrm{v})$ $\mathrm{NaCl}$.

Cheeses were artificially contaminated twice with $\mathrm{Lis}$ teria after 7 and 8 days ripening. Listeria inoculum was prepared as follows. Overnight cultures of 4 Listeria innocua strains were mixed in a 1:1:1:1 ratio, diluted $10^{\prime} 000$ times in $0.9 \%(\mathrm{w} / \mathrm{v}) \mathrm{NaCl}$, and $0.3 \mathrm{ml}$ of the dilution were added to each smear brine after the centrifugation step, to reach a concentration of ca. $5 \times 10^{3} \mathrm{CFU} \mathrm{ml}^{-}$ 1 . The brushes and wooden shelves were washed and autoclaved prior to each use. Wooden shelves were first changed after one week and every three weeks thereafter. The $\mathrm{pH}$ of the cheese surface was periodically measured in situ using a flat membrane electrode (InLab ${ }^{\odot}$ Surface, Mettler-Toledo, Greifensee, Switzerland).

\section{Microbial analyses of cheese surface during ripening experiments}

Approximately $25 \mathrm{~cm}^{2}$ of cheese surface were scraped off using sterile cotton rolls (IVF Hartmann, Neuhausen, Switzerland) and aseptically transferred into a stomacher bag. Each sample was suspended in $25 \mathrm{ml}$ pre-heated $\left(45^{\circ} \mathrm{C}\right)$ peptone water, composed of $1 \%(\mathrm{w} / \mathrm{v})$ casein peptone, $0.5 \%(\mathrm{w} / \mathrm{v}) \mathrm{NaCl}$ and $2 \%(\mathrm{w} / \mathrm{v})$ tri-sodium citrate dehydrate, all from Merck (Dietikon, Switzerland), and homogenized for $4 \mathrm{~min}$ using a Stomacher (Silver Masticator; IUL Instruments $\mathrm{GmbH}$, Königswinter, Germany). $1 \mathrm{ml}$ of this solution was submitted to total DNA extraction for TTGE as described above. Serial dilutions in $0.9 \%(\mathrm{w} / \mathrm{v}) \mathrm{NaCl}$ were prepared and plated on TGYA, PY agar and Palcam agar. At the end of ripening, $10 \mathrm{~g}$ of smear were harvested and tested for the presence of Listeria using an enrichment procedure as described above. 


\section{Acknowledgements}

This work was supported by the Research Station Agroscope LiebefeldPosieux ALP, Bern, Switzerland. We thank Daniel Goy for sharing expertise in cheese ripening. We also thank Hélène Berthoud and Monika Haueter for excellent assistance with sequencing and DNA extraction protocols.

\section{Author details}

'Laboratory of Food Biotechnology, Institute of Food Science and Nutrition, ETH-Zurich, 8092 Zurich, Switzerland. ${ }^{2}$ Research Station Agroscope LiebefeldPosieux ALP, 3003 Bern, Switzerland.

\section{Authors' contributions}

ER carried out the experiments, evaluated the results and drafted the manuscript. MH participated in the creation of the TTGE database and in the repetition of the cheese experiment. SMS and EEM participated in the conception and coordination of the study and revision of the manuscript. $\mathrm{CL}$ provided guidance during the whole study and revised the manuscript. All authors read and approved the final manuscript.

Received: 5 November 2009 Accepted: 11 March 2010 Published: 11 March 2010

\section{References}

1. Bockelmann W, Hoppe-Seyler T: The surface flora of bacterial smearripened cheeses from cow's and goat's milk. Int Dairy J 2001, 11:307-314.

2. Mounier J, Gelsomino R, Goerges S, Vancanneyt M, Vandemeulebroecke K, Hoste B, Scherer S, Swings J, Fitzgerald GF, Cogan TM: Surface microflora of four smear-ripened cheeses. Appl Environ Microbiol 2005, 71:6489-6500.

3. Wenning M, Theilmann V, Scherer S: Rapid analysis of two food-borne microbial communities at the species level by Fourier-transform infrared microspectroscopy. Environ Microbiol 2006, 8:848-857.

4. Ogier JC, Lafarge V, Girard V, Rault A, Maladen V, Gruss A, Leveau JY, Delacroix-Buchet A: Molecular fingerprinting of dairy microbial ecosystems by use of temporal temperature and denaturing gradient gel electrophoresis. Appl Environ Microbiol 2004, 70:5628-5643.

5. Feurer $C$, Irlinger $F$, Spinnler HE, Glaser $P$, Vallaeys T: Assessment of the rind microbial diversity in a farmhouse-produced vs a pasteurized industrially produced soft red-smear cheese using both cultivation and rDNA-based methods. J Appl Microbiol 2004, 97:546-556.

6. Rademaker JLW, Peinhopf M, Rijnen L, Bockelmann W, Noordman WH: The surface microflora dynamics of bacterial smear-ripened Tilsit cheese determined by T-RFLP DNA population fingerprint analysis. Int Dairy J 2005, 15:785-794.

7. Bockelmann W: Development of defined surface starter cultures for the ripening of smear cheeses. Int Dairy J 2002, 12:123-131.

8. Rea MC, Görges S, Gelsomino R, Brennan NM, Mounier J, Vancanneyt M, Scherer S, Swings J, Cogan TM: Stability of the biodiversity of the surface consortia of Gubbeen, a red-smear cheese. J Dairy Sci 2007, 90:2200-2210.

9. Maoz A, Mayr R, Scherer S: Temporal stability and biodiversity of two complex antilisterial cheese-ripening microbial consortia. Appl Environ Microbiol 2003, 69:4012-4018.

10. Ishikawa M, Kodama K, Yasuda H, Okamoto-Kainuma A, Koizumi K, Yamasato K: Presence of halophilic and alkaliphilic lactic acid bacteria in various cheeses. Lett Appl Microbiol 2007, 44:308-313.

11. Jany JL, Barbier G: Culture-independent methods for identifying microbial communities in cheese. Food Microbiol 2008, 25:839-848.

12. Ogier JC, Son O, Gruss A, Tailliez P, Delacroix-Buchet A: Identification of the bacterial microflora in dairy products by temporal temperaturegradient gel electrophoresis. Appl Environ Microbiol 2002, 68:3691-3701.

13. Swaminathan B, Gerner-Smidt P: The epidemiology of human listeriosis. Microbes Infect 2007, 9:1236-1243.

14. Rudolf M, Scherer S: High incidence of Listeria monocytogenes in European red smear cheese. Int J Food Microbiol 2001, 63:91-98,

15. Eppert I, Valdés-Stauber N, Götz H, Busse M, Scherer S: Growth reduction of Listeria spp. caused by undefined industrial red smear cheese cultures and bacteriocin-producing Brevibacterium linens as evaluated in situ on soft cheese. Appl Environ Microbiol 1997, 63:4812-4817.

16. Loessner M, Guenther S, Steffan S, Scherer S: A pediocin-producing Lactobacillus plantarum strain inhibits Listeria monocytogenes in a multispecies cheese surface microbial ripening consortium. Appl Environ Microbiol 2003, 69:1854-1857.
17. Mayr R, Fricker M, Maoz A, Scherer S: Anti-listerial activity and biodiversity of cheese surface cultures: influence of the ripening temperature regime. Eur Food Res Technol 2004, 218:242-247.

18. Ryser ET, Maisnier-Patin S, Gratadoux JJ, Richard J: Isolation and identification of cheese-smear bacteria inhibitory to Listeria spp. Int J Food Microbiol 1994, 21:237-246.

19. Carnio MC, Eppert I, Scherer S: Analysis of the bacterial surface ripening flora of German and French smeared cheeses with respect to their antilisterial potential. Int J Food Microbiol 1999, 47:89-97.

20. Carnio MC, Höltzel A, Rudolf M, Henle T, Jung G, Scherer S: The macrocyclic peptide antibiotic micrococcin P-1 is secreted by the foodborne bacterium Staphylococcus equorum WS 2733 and inhibits Listeria monocytogenes on soft cheese. Appl Environ Microbiol 2000, 66:2378-2384.

21. Saubusse M, Millet L, Delbès C, Callon C, Montel MC: Application of Single Strand Conformation Polymorphism - PCR method for distinguishing cheese bacterial communities that inhibit Listeria monocytogenes. Int J Food Microbiol 2007, 116:126-135.

22. Goerges S, Mounier J, Rea MC, Gelsomino R, Heise V, Beduhn R, Cogan TM, Vancanneyt M, Scherer S: Commercial ripening starter microorganisms inoculated into cheese milk do not successfully establish themselves in the resident microbial ripening consortia of a South German red smear cheese. Appl Environ Microbiol 2008, 74:2210-2217.

23. Brennan NM, Ward AC, Beresford TP, Fox TP, Goodfellow M, Cogan TM: Biodiversity of the bacterial flora on the surface of a smear cheese. Appl Environ Microbiol 2002, 68:820-830.

24. Mounier J, Monnet C, Jacques N, Antoinette A, Irlinger F: Assessment of the microbial diversity at the surface of Livarot cheese using culturedependent and independent approaches. Int I Food Microbiol 2009, 133(1-2):31-7.

25. Schubert K, Ludwig W, Springer N, Kroppenstedt RM, Accolas JP, Fiedler F: Two coryneform bacteria isolated from the surface of French Gruyere and Beaufort cheeses are new species of the genus Brachybacterium: Brachybacterium alimentarium sp. nov. and Brachybacterium tyrofermentans sp. nov. Int J Syst Bacteriol 1996, 46:81-87.

26. Callon C, Duthoit F, Delbès C, Ferrand M, Le Frileux Y, De Crémoux R, Montel MC: Stability of microbial communities in goat milk during a lactation year: Molecular approaches. Syst Appl Microbiol 2007, 30:547-560.

27. Irlinger F, Morvan A, El Solh N, Bergere JL: Taxonomic characterization of coagulase-negative staphylococci in ripening flora from traditional French cheeses. Syst Appl Microbiol 1997, 20:319-328.

28. Bockelmann W, Krusch U, Engel G, Klijn N, Smit G, Heller KJ: The microflora of Tilsit cheese. Part 1. Variability of the smear flora. Nahrung 1997, 41:208-212.

29. Place RB, Hiestand D, Gallmann HR, Teuber M: Staphylococcus equorum subsp linens, subsp nov., a starter culture component for surface ripened semi-hard cheeses. Syst Appl Microbiol 2003, 26:30-37.

30. Foulquié Moreno MR, Sarantinopoulos P, Tsakalidou E, De Vuyst L: The role and application of enterococci in food and health. Int J Food Microbiol 2006, 106:1-24.

31. Franz CM, Stiles ME, Schleifer KH, Holzapfel WH: Enterococci in foods - a conundrum for food safety. Int J Food Microbiol 2003, 88:105-122.

32. Collins MD, Hutson RA, Falsen E, Sjödén B: Facklamia tabacinasalis sp. nov., from powdered tobacco. Int J Syst Microbiol 1999, 49:1247-1250.

33. Delbès C, Ali-Mandjee L, Montel MC: Monitoring bacterial communities in raw milk and cheese by culture-dependent and -independent $16 \mathrm{~S}$ rRNA gene-based analyses. Appl Environ Microbiol 2007, 73:1882-1891.

34. Hantsis-Zacharov E, Halpern M: Culturable psychrotrophic bacterial communities in raw milk and their proteolytic and lipolytic traits. App/ Environ Microbiol 2007, 73:7162-7168.

35. Takamatsu D, Ide H, Osaki M, Sekizaki T: Identification of Facklamia sourekii from a lactating cow. J Vet Med Sci 2006, 68:1225-1227.

36. Mounier J, Goerges $S$, Gelsomino R, Vancanneyt M, Vandemeulebroecke K, Hoste B, Brennan NM, Scherer S, Swings J, Fitzgerald GF, Cogan TM: Sources of the adventitious microflora of a smear-ripened cheese. J Appl Microbiol 2006, 101:668-681.

37. Ishikawa $M$, Nakajima $K$, Yanagi $M$, Yamamoto $Y$, Yamasato $K$ : Marinilactibacillus psychrotolerans gen. nov., sp nov., a halophilic and alkaliphilic marine lactic acid bacterium isolated from marine organisms in temperate and subtropical areas of Japan. Int I Syst Evol Microbiol 2003, 53:711-720. 
38. Ishikawa M, Tanasupawat S, Nakajima K, Kanamori H, Ishizaki S, Kodama K, Okamoto-Kainuma A, Koizumi Y, Yamamoto Y, Yamasato K: Alkalibacterium thalassium sp. nov., Alkalibacterium pelagium sp. nov., Alkalibacterium putridalgicola sp. nov. and Alkalibacterium kapii sp. nov., slightly halophilic and alkaliphilic marine lactic acid bacteria isolated from marine organisms and salted foods collected in Japan and Thailand. Int J Syst Evol Microbiol 2009, 59:1215-1226.

39. Leclercq-Perlat MN, Oumer A, Bergere JL, Spinnler HE, Corrieu G: Growth of Debaryomyces hansenii on a bacterial surface-ripened soft cheese. J Dairy Res 1999, 6:271-281.

40. Brennan NM, Cogan TM, Loessner M, Scherer S: Bacterial Surface-ripened Cheeses. Cheese: Chemistry, Physics and Microbiology Amsterdam: Elsevier Academic PressFox PF, McSweeney PLH, Cogan TM, Guinee TP , 32004 , 2:199-225.

41. Mounier J, Irlinger F, Leclercq-Perlat MN, Sarthou AS, Spinnler HE, Fitzgerald G, Cogan TM: Growth and colour development of some surface ripening bacteria with Debaryomyces hansenii on aseptic cheese curd. J Dairy Res 2006, 73:441-448.

42. Mounier J, Rea MC, O'Connor PM, Fitzgerald GF, Cogan TM: Growth characteristics of Brevibacterium, Corynebacterium, Microbacterium, and Staphylococcus spp. isolated from surface-ripened cheese. Appl Environ Microbiol 2007, 73:7732-7739.

43. Pine L, Malcolm GB, Brooks JB, Daneshvar MI: Physiological studies on the growth and utilization of sugars by Listeria species. Can J Microbiol 1989, 35:245-254.

44. Premaratne RJ, Lin WJ, Johnson EA: Development of an improved chemically defined minimal medium for Listeria monocytogenes. Appl Environ Microbiol 1991, 57:3046-3048.

45. Tsai HN, Hodgson DA: Development of a synthetic minimal medium for Listeria monocytogenes. Appl Environ Microbiol 2003, 69:6943-6945.

46. Lungu B, Ricke SC, Johnson MG: Growth, survival, proliferation and pathogenesis of Listeria monocytogenes under low oxygen or anaerobic conditions: A review. Anaerobe 2009, 15:7-17.

47. Barreteau H, Kovac A, Boniface A, Sova M, Gobec S, Blanot D: Cytoplasmic steps of peptidoglycan biosynthesis. Microbiol Rev 2008, 32:168-207.

48. Sentandreu R, Northcote DH: Yeast cell-wall synthesis. Biochem J 1969 115:231-240

49. Hain T, Chatterjee SS, Ghai R, Kuenne CT, Billionm A, Steinweg C, Domann E, Kärst U, Jänsch L, Wehland J, Eisenreich W, Bacher A, Joseph B, Schär J, Kreft J, Klumpp J, Loessner MJ, Dorscht J, Neuhaus K, Fuchs TM, Scherer S, Doumith M, Jacquet C, Martin P, Cossart P, Rusniock C, Glaser P, Buchrieser C, Goebel W, Chakraborty T: Pathogenomics of Listeria spp. Int J Med Microbiol 2007, 297:541-557.

50. Chavagnat F, Haueter M, Jimeno J, Casey MG: Comparison of partial tuf gene sequences for the identification of lactobacilli. Microbiol Lett 2002, 2:177-183.

51. Kuhnert P, Capaul SE, Nicolet J, Frey J: Phylogenetic positions of Clostridium chauvoei and Clostridium septicum based on 16S rRNA gene sequences. Int J Syst Bacteriol 1996, 4:1174-1176.

52. Oberreuter $\mathrm{H}$, Charzinski J, Scherer S: Intraspecific diversity of Brevibacterium linens, Corynebacterium glutamicum and Rhodococcus erythropolis based on partial 16S rDNA sequence analysis and Fouriertransform infrared (FT-IR) spectroscopy. Microbiology 2002, 148:1523-1532.

53. Liebgott PP, Joseph M, Fardeau ML, Cayol JL, Falsen E, Chamkh F, Qatibi AA, Labatt M: Clostridiisalibacter paucivorans gen. nov., sp nov., a novel moderately halophilic bacterium isolated from olive mill wastewater. Int J Syst Evol Microbiol 2008, 58:61-67.

doi:10.1186/1471-2180-10-74

Cite this article as: Roth et al:: Population dynamics of two antilisterial cheese surface consortia revealed by temporal temperature gradient gel electrophoresis. BMC Microbiology 2010 10:74.

\section{Submit your next manuscript to BioMed Central and take full advantage of:}

- Convenient online submission

- Thorough peer review

- No space constraints or color figure charges

- Immediate publication on acceptance

- Inclusion in PubMed, CAS, Scopus and Google Scholar

- Research which is freely available for redistribution

Submit your manuscript at www.biomedcentral.com/submit
Biomed Central 